\title{
Anticarbohydrate antibodies in patients with inflammatory bowel disease.
}

\author{
Mohammed Fakhraldeen, Lecturer of internal medicine, \\ Faculty of medicine, Mansoura University \\ Huseen Saad Mostafa, Consultant clinical pathology, \\ King Fahd hospital, Riyadh, Saudi Arabia
}

\begin{abstract}
Objective:

Evaluating the prevalence of antichitobioside carbohydrate antibody (ACCA), antilaminaribioside carbohydrate antibodies (ALCA), antimannobioside carbohydrate antibodies (AMCA) and anti-Saccharomyces cerevisiae antibodies (ASCA), in patients with inflammatory bowel disease (IBD).
\end{abstract}

\section{Subjects and methods:}

268 serum samples were used; 115 Crohn's disease (CD), 83 ulcerative colitis, and 70 healthy control samples. All samples were evaluated using enzyme-linked immunosorbent assay for the following four anticarbohydrate antibodies: ACCA, ALCA, AMCA, and ASCA.

\section{Results:}

In patients with Crohn's disease the prevalence of the anticarbohydrate antibodies was: ASCA 69\%, AMCA 32\%, ACCA 28\% and ALCA 24\% with the highest prevalence being for ASCA (P-value $<0.0001)$ while in patients with ulcerative colitis the prevalence was: ACCA $46 \%$, AMCA 35\%, ALCA 23\% and ASCA 15\% with the highest prevalence being for ACCA (Pvalue $<0.001)$.

\section{Conclusion:}

Anticarbohydrate antibodies are significantly present in patients with IBD. The use of a panel of anticarbohydrate antibodies may provide additional help in distinguishing IBD from non-IBD disease patterns and narrow the range of differential diagnosis in these patients.

\section{Introduction}

In the past decade, significant advances have been made in the discovery of immunological processes related to inflammatory bowel disease (IBD); evaluation of these processes is the subject of many publications, which report correlation between different serological markers and IBD; however, relying exclusively on serum antibodies for IBD diagnosis is not justified yet, because the available humoral immunological markers are neither adequately sensitive nor sufficiently specific [Marteu P, 2002]. Currently, a serology panel that includes perinuclear antineutrophil cytoplasmic antibodies (p-ANCA) and antiSaccharomyces cerevisiae antibodies (ASCA) is used as an auxiliary diagnostic tool of IBD [Vermeire et al, 2004]. A number of studies have reported that ASCA titers are significantly greater and highly specific for Crohn's disease (CD) [Quinton et al, 1998 and Nielsen et al, 2000]. Recently, immune responsiveness to some microbe-derived antigens such as outer 
membrane porin $\mathrm{C}(\mathrm{OmpC})$ of Escherichia coli [Ferrante et al, 2007], I2 DNA fragment of Pseudomonas fluorescens [Ferrante et al, 2007], or flagellin-derived protein Cbir1 [Targan et al, 2005 and Papp et al, 2007] have been described as contributing factors in the pathogenesis of IBD. Dotan et al. [2006] indicated that patients with $\mathrm{CD}$ might have elevated serum levels of antibodies specific for certain carbohydrate structures and these anticarbohydrate assays are based on the oligosaccharides; chitobioside carbohydrate, laminaribioside carbohydrate, and mannobioside carbohydrate, which are the predominant cell wall surface components in many saprophytic and pathogenic fungi, yeast, bacteria, as well as protozoa and viruses. In humans, these carbohydrates can trigger essential immunological processes, including T-cell activation, differentiation, and survival [Perzer et al, 1991 and Schwarz et al, 2003]. It was reported that anti-Cbir1, anti$\mathrm{I} 2$, and anti-OmpC are associated with more complex CD course and patients expressing anti-I2 are significantly more likely to have fibrostenosing $\mathrm{CD}$ and require small bowel surgery [Ferrante et al, 2007]. A serum response to flagellin-like antigen Cbir1 is associated with small-bowel, penetrating, and fibrostenosing disease features [Targan et al, 2005]. ASCA, ALCA, and anti-
OmpC are linked to the ileal involvement; anti-OmpC and p-ANCA in CD can indicate UC-like behaviour [Papp et al, 2007].It is hypothesized that anticarbohydrate antibodies could improve the diagnostic accuracy of serological testing in IBD and, in particular, could contribute to refining the differential diagnosis of CD and UC and IBD/non-IBD involvement [Targan et al, 2005]. The aim of this study was to investigate the prevalence of ACCA, ALCA, AMCA and ASCA in IBD patients.

\section{Subjects and Methods}

This study was conducted at the gastroenterology and endoscopy unit, King Fahd hospital, Riyadh, Saudi Arabia. A total of 268 serum samples were included in the study: $115 \mathrm{CD}, 83 \mathrm{UC}$ and 70 healthy age and sex-matched blood donors. All serum samples were analyzed for ASCA, ACCA, ALCA, and AMCA levels using the ELISA method. All patients included in the study were already diagnosed to have IBD (Crohn's disease or ulcerative colitis) and are under regular follow up. Data about age, disease duration and disease location were collected from the medical records of the patients.

Table 1 shows criteria of Crohn's disease patients:

\begin{tabular}{|l|l|}
\hline Number & 115 \\
\hline Male/ Female & $65 \mid 50$ \\
\hline Mean age (years) & $30.7 \pm 6.5$ \\
\hline Disease duration (years) & $6-15$ \\
\hline Disease location: & \\
terminal ilium & $21(18 \%)$ \\
Colon & $28(24 \%)$ \\
Ileocolon & $66(58 \%)$ \\
\hline
\end{tabular}


Table 2 shows criteria of ulcerative colitis patients:

\begin{tabular}{|l|l|}
\hline Number & 83 \\
\hline Male|Female & $46 \mid 37$ \\
\hline Mean age (years) & $38.8 \pm 9.8$ \\
\hline Disease duration (years) & $7-15$ \\
\hline Disease location: & \\
Proctitis & $24(29 \%)$ \\
Distal and left-sided colitis & $40(48 \%)$ \\
Pancolitis & $19(23 \%)$ \\
\hline \multicolumn{2}{|l|}{ Serum ASCA, ACCA, ALCA, and AMCA were measured using ELISA method }
\end{tabular}

The $\chi^{2}$-test and Mann-Whitney's $U$-test were used for assessment of prevalence rates and evaluation of the differences in antibody titers. P-values of less than 0.05 were considered significantly different.

\section{Results}

ASCA, AMCA, ALCA, and ACCA reactivity in the IBD and healthy groups:

\section{In the CD sample group;}

1-79 serum samples out of 115 were ASCA-positive, equalling a prevalence of $69 \%$.

2-32 samples out of 115 were ACCA positive, equalling a prevalence of $28 \%$.

3-28 samples out of 115 were ALCA positive equalling a prevalence of $24 \%$.

4- 37 samples out of 115 were AMCA positive equalling a prevalence of (32\%).

5-25\% of the CD serum samples were positive for more than one serological marker.

\begin{tabular}{|l|l|l|}
\hline ASCA & 79 & $69 \%$ \\
\hline ACCA & 32 & $28 \%$ \\
\hline ALCA & 28 & $24 \%$ \\
\hline AMCA & 37 & $32 \%$ \\
\hline
\end{tabular}

\section{In the UC sample group;}

1-12 serum samples out of 83 were ASCA positive equalling a prevalence of $15 \%$.

2-38 serum samples out of 83 were ACCA positive, equalling a prevalence of $46 \%$.

3- 19 serum samples out of 83 were ALCA positive, equalling a prevalence of $23 \%$.

4- 29 serum samples out of 83 were AMCA positive equalling a prevalence of $35 \%$

5-20\% of the UC serum samples were positive for more than one serological marker.

\begin{tabular}{|l|l|l|}
\hline ASCA & 12 & $15 \%$ \\
\hline ACCA & 38 & $46 \%$ \\
\hline ALCA & 19 & $23 \%$ \\
\hline AMCA & 29 & $35 \%$ \\
\hline
\end{tabular}




\section{IN the healthy controls;}

1-4 serum samples out of 70 were ASCA positive equalling a prevalence of $6 \%$.

2-8 serum samples out of 70 were ACCA positive, equalling a prevalence of $12 \%$.

3- 4 serum samples out of 70 were ALCA positive, equalling a prevalence of $6 \%$.

4- 8 serum samples out of 70 were AMCA positive equalling a prevalence of $12 \%$.

\begin{tabular}{|l|l|l|}
\hline ASCA & 4 & $6 \%$ \\
\hline ACCA & 8 & $12 \%$ \\
\hline ALCA & 4 & $6 \%$ \\
\hline AMCA & 8 & $12 \%$ \\
\hline
\end{tabular}

The differences in the prevalence of the anticarbohydrate antibodies between the patient group and the control group were highly significant, with the highest prevalence is for ASCA in the Crohn's disease patients $(69 \%$ with the P-value $<0.0001)$ and for ACCA in the ulcerative colitis patients $(46 \%$ with the P-value $<0.001)$.

\section{Discussion}

Similar to many systemic and organspecific autoimmune disorders, IBD is associated with various immunological abnormalities and can represent a process of immune dysfunction [Mow et al, 2004]. However, unlike most autoimmune disorders, IBD occurs at a mucosal site facing the intestinal lumen, thus the primary immune target in IBD may be an extrinsic antigen such as a chronic microbial colonist [Lennard-Jones, 1989]. The human gut microflora is composed of hundreds of bacterial species [Satsangi et al, 2006], the behavior of the intestinal microflora may be either commensal or pathogenic [Silverberg et al, 2005]. One of the numerous factors that determine a particular host-microbial relationship is the protein-glycan interaction, which control essential immunological responses, including lymphocyte activation, differentiation and survival [Schwarz et al, 2003]. It is possible that carbohydrate (glycan) antigens of endogenous microflora can contribute to the immune-mediated damage of the intestinal mucosa seen in IBD [Langholz E, 1999].

In our study, we evaluated the prevalence of 4 anticarbohydrate antibodies (ASCA, ACCA, ALCA and AMCA) in patients with inflammatory bowel disease; in patients with $\mathrm{CD}$, we found a prevalence of $69 \%$ for ASCA, $28 \%$ for ACCA, $44 \%$ for ALCA and $32 \%$ for AMCA with the highest prevalence being for ASCA (Pvalue $<0.0001$ ). In patients with $\mathrm{UC}$, we found a prevalence of $15 \%$ for ASCA, $46 \%$ for ACCA, 23\% for ALCA and 35\% for AMCA with the highest prevalence being for ACCA (P-value<0,001).Thus, identification of novel antibodies associated with IBD would provide an advance to the current diagnostic tools [Perzer et al, 1991].

Anticarbohydrate antibody assays are based on the oligosaccharides chitobioside, laminaribioside, and mannobioside carbohydrates, these glycans are cell-wall surface components in many saprophytic and pathogenic microbes [Silverberg et al, 2005]. The immune system in the intestinal mucosa of healthy individuals is tolerant to microbial carbohydrate (glycan) antigens [Wen and Fiocchi, 2004]. In patients with IBD, there is a loss of immunological tolerance to their 'own' resident microbes present on the mucosal surface, however, whether antibodies to these carbohydrate antigens are directly causative of IBD with the participation in the inflammatory cascade, or are simply an epiphenomenon of the immunopathologic inflammation, is uncertain [Duchmann et al 1995].Similar 
results regarding the association between IBD and anticarbohydrate antibodies were obtained in other studies [Papp et al, 2008]. However, none of the current available biomarker tests/ assays can be used as stand-alone tools in the diagnosis of IBD; therefore, it can only be recommended as an adjunct to conventional methods for diagnosis of the disease [Vermeire et al, 2006].

Anti-Saccharomyces cerevisiae antibodies (ASCA) and perinuclear antineutrophil cytoplasmic antibodies (pANCA) were the first extensively characterized serological IBD markers; ASCA is more associated with Crohn's disease (CD) while pANCA is more associated with ulcerative colitis (UC) [Duchmann et al, 1995]. Three additional serum biomarkers were introduced later, including antibodies against outer membrane porin $\mathrm{C}$ (anti-OmpC), Pseudomonas fluorescens bacterial sequence I2 (anti-I2), and bacterial flagellin (anti-Cbir 1) [Langholz E, 1999]. Although data from different studies vary, combinations of more than one of the 5 serological markers have been shown to have the most clinical value for example; ASCA and pANCA together have a specificity of approximately $90 \%$ for both CD and UC [Vermeire et al, 2006]. These markers have been demonstrated as not only being useful for differentiating IBD from healthy control or CD from UC, but also as potential indicators and/or predictors for disease activity/location, disease course/complication, need for surgery, and prognosis of therapy. For example:

1-CD patients who are positive for multiple anti-microbial antibodies (ASCA, antiOmpC, anti-Cbir1, and anti-I2) have increased risk of having more complicated disease

2-patients who are positive in all four of these biomarkers have 11-fold increased risk to develop penetrating and/or stricturing disease

3-CD patients positive for three markers (anti-OmpC, anti-Cbir1, and anti-I2) are more likely to have small bowel surgery than those who were negative for these markers [Buhner et al, 2006].

Another importance of these serological biomarkers include their potential value as subclinical biomarkers and their inherent geographic/ethnic heterogeneity: different studies have shown that the prevalence of ASCA positivity is significantly higher $(20 \%-25 \%)$ in unaffected first-degree relatives of patients with $\mathrm{CD}$ compared to general healthy populations $(0 \%-10 \%)$, indicating a familial association denoting that ASCA may be a potential subclinical biomarker for CD [Lawrance et al, 2004].

Ferrante et a l [2007] reported a study that involved a large cohort, including 1225 IBD patients. In this study, ACCA, ALCA, AMCA, ASCA and anti-OmpC were analyzed. $76 \%$ of $\mathrm{CD}$ patients are positive for at least one of the 5 markers. Simondi et a $l$ [2008] stated that, while the level of ASCA appeared to be associated with ileal disease and penetrating/structuring disease, level of ALCA has a similar trend, but did not reach statistic significance $(P=0.07$ and $P=0.09$, respectively) also they reported that $\mathrm{CD}$ patients with at least one affected first-degree relative exhibited significantly higher levels of ALCA than those without familial cases $(\mathrm{P}=0.0005)$, suggestive of a familial association of ALCA. Similar results on antiglycan antibodies were reported by Papp et al [2007].In another study [Pang et al, 2005] that involved 652 patients with IBD, $66.2 \%$ of $\mathrm{CD}$ patients were positive for at least one of the 5 biomarkers tested, including ASCA, ALCA, ACCA, AMCA, and antiOmpC.

Results from our study and all other studies indicated the importance of anticarbohydrate antibodies as an adjunct tool in the diagnosis of IBD and narrowing the range of differential diagnosis in such patients, however none of these serological markers can be used as a sole diagnostic method for IBD and their value is confirmatory to other conventional methods of diagnosis. 


\section{Conclusion}

Anticarbohydrate antibodies are significantly present in patients with IBD. ASCA is present in $69 \%$ of patients with $\mathrm{CD}$ and ACCA is present in $46 \%$ of patents with UC. The use of a panel of anticarbohydrate antibodies may provide additional help in distinguishing IBD from non-IBD disease patterns and narrowing the range of differential diagnosis in such patients.

\section{References}

- Buhner S, Buning C, Genschel J, Kling K, Herrmann D, Dignass A, Kuechler I, Krueger S, Schmidt HH, Lochs H (2006). Genetic basis for increased intestinal permeability in families with Crohn's disease: role of CARD15 3020insC mutation? Gut ; 55: 342-347

- Dotan NIR, Fishman S, Dgani Y, Schwartz M, Karban A, Lerner A (2006). Antibodies against laminaribioside and chitobioside are novel serologic markers in Crohn's disease. Gastroenterology ; 131:366-378.

- Duchmann R, Kaiser I, Hermann E, Mayet W, Ewe K, Meyer zum Buschenfelde KH (1995). Tolerance exists towards resident intestinal flora but is broken in active inflammatory bowel disease (IBD). Clin Exp Immunol ; 102:448-455.

- Ferrante M, Henckaerts L, Joossens M, Pierik M, Joossens S, Dotan N (2007). New serological markers in inflammatory bowel disease are associated with complicated disease behaviour. Gut ; 56:1394-1403.

- Langholz E. Ulcerative colitis (1999). An epidemiological study based on a regional inception cohort, with special reference to disease course and prognosis. Dan Med Bull ; 46:400-415.

- Lawrance IC, Murray K, Hall A, Sung JJ, Leong R (2004). A prospective comparative study of ASCA and pANCA in Chinese and Caucasian IBD patients. Am J Gastroenterol ; 99: 2186-2194
- Lennard-Jones JE. Classification of inflammatory bowel disease (1998). Scand J Gastroenterol ; 170 (Suppl):2-6.

- Marteau P.9 (2002). Inflammatory bowel disease. Endoscopy ; 34:63-68.

Mow WS, Vasiliauskas EA, Lin YC, Fleshner PR, Papadakis KA, Taylor KD (2004). Association of antibody responses to microbial antigens and complications of small bowel Crohn's disease. Gastroenterology ; 126:414-424.

- Nielsen OH, Vainer B, Madsen SM, Seidelin JB, Heegaard NH (2002). Established and emerging biological activity markers of inflammatory bowel disease. Am J Gastroenterol ; 95:359367.

- Pang Z, Otaka K, Maoka T, Hidaka K, Ishijima S, Oda M, Ohnishi M (2005). Structure of beta-glucan oligomer from laminarin and its effect on human monocytes to inhibit the proliferation of U937 cells. Biosci Biotechnol Biochem; 69: 553-558

- Papp M, Istvan Altorjay I, Norman GL, Shums Z, Palatka K, Vitalis Z (2007).

Seroreactivity to microbial components in Crohn's disease is associated with ileal involvement, non-inflammatory disease behaviour and NOD2/ CARD15 genotype, but not with risk for surgery in a Hungarian cohort of IBD patient. Inflamm Bowel Dis ; 13:984-992.

- Papp M, Altorjay I, Dotan N, Palatka K, Foldi I, Tumpek J (2008). New serological markers for inflammatory bowel disease are associated with earlier age at onset, complicated disease behavior, risk for surgery, and NOD2/CARD15 genotype in a Hungarian IBD cohort. Am J Gastroenterol ; 103:665-681.

- Pirzer U, Schonhaar A, Fleischer B, Hermann E, Meyer KH (1991). Reactivity of infiltrating $\mathrm{T}$ lymphocytes with microbial antigens in Crohn's disease. Lancet ; 338:1238-1239.

- Quinton JF, Sendid B, Reumaux D (1998). Anti-Saccharomyces cerevisiae mannan antibodies combined with antineutrophil cytoplasmic autoantibodies in inflammatory bowel disease: prevalence and diagnostic role. Gut ; 42:788-791.

- Satsangi J, Silverberg MS, Vermeire S, Colombel JF (2006). The Montreal classification of inflammatory bowel 
disease: controversies, consensus, and implications. Gut ; 55:749-753.

- Schwarz M, Spector L, Gargir A, Shtevi A, Gortler M, Altstock RT (2003). A new kind of carbohydrate array, its use for profiling anticarbohydrate antibodies, and the discovery of a novel human cellulosebinding antibody. Glycobiology ; 13:749-754.

- Silverberg MS, Satsangi J, Ahmad T, Arnott ID, Bernstein CN, Brant SR (2005). Toward an integrated clinical, molecular and serological classification of inflammatory bowel disease: report of a Working Party of the 2005 Montreal World Congress of Gastroenterology. Can J Gastroenterol ; 19 (Suppl A):5.

- Simondi D, Mengozzi G, Betteto S, Bonardi R, Ghignone RP, Fagoonee S, Pellicano R, Sguazzini C, Pagni R, Rizzetto M, Astegiano M (2008). Antiglycan antibodies as serological markers in the differential diagnosis of inflammatory bowel disease. Inflamm Bowel Dis ; 14: 645- 651

- Targan S, Landers CJ, Yang H, Lodes MJ, Cong Y, Papadakis KA (2005). Antibodies to CBir1 flagellin define a unique response that is associated independently with complicated Crohn's disease. Gastroenterology ; 128:20202028.

- Vermeire S, Rutgeerts P (2004). Antibody responses in Crohn's disease. Gastroenterology ; 126:601-604.

- Vermeire S, Van Assche G, Rutgeerts P (2006). Laboratory markers in IBD: useful, magic, or unnecessary toys? Gut ; 55:556-562

- Wen Z, Fiocchi C (2004). Inflammatory bowel disease: autoimmune or immunemediated pathogenesis? Clin Dev Immunol ; 11:195-204. 



\section{مضادات الكربو هيدرات فى مرض القناة الهضمية الالتهابى}

محمد فخر الدين ـ مدرس الباطنةكلية الطب-جامعة المنصورة

حسين سعد مصطفى_استثارى الباتولوجيا الاكلينيكية

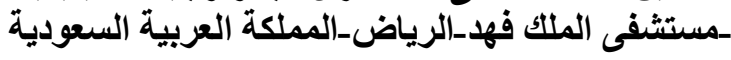

يهدف البحث الى معرفة نسبة وجود مضادات الكاربو هيدر ات (ACCA,ALCA,AMCA,ASCA ) فى مرض القناة الهضمية الالتهابى .ولقد نم البحث على 268 عينة دم من : 115 مريض بمرض كرون- 83 مريض بالقولون التقرحى- 70 شخص سليم كمجو عة ضابطة. ونم قياس مضادات الكاربو هيدر ات الاربعة عن طريق تقنية , 28\%=ACCA , 32\%=AMCA , 69\%=ASCA ووجد فى مرضى كرون ان نسبة وجود ELISA 23\% =ALCA ,35\%=AMCA : 24\% = وفى مرضى القولون التقرحى كانت النسب كالاتى =ALCA 46\% =ACCA, 15\%=ASCA ونستخلص من البحث ان مضادات الكاربو هيدرات توجد في نسبة عالية من المرضى ويمكن ان لها فائدة تتخيصية كبيرة. 